\begin{tabular}{|c|c|c|}
\hline BIODIK & $\begin{array}{c}\text { BIODIK: Jurnal IImiah Pendidikan Biologi } \\
\text { ISSN 2580-0922 (online), ISSN 2460-2612 (print) } \\
\text { Volume 7, Nomor 02, Tahun 2021, Hal. 63-70 } \\
\text { Available online at: } \\
\text { https://online-journal.unja.ac.id/biodik }\end{array}$ & BIODIK $(Q)$ \\
\hline
\end{tabular}

Research Article

OPEN ACCESS

\title{
Peranan Self Efficacy dan Self Regulated Learning Terhadap Prestasi Akademik Mahasiswa
}

\section{(The Role of Self Efficacy and Self Regulated Learning on Student Academic Achievement)}

\author{
Anisa*, Nurul Magfirah, Rahmatia Thahir \\ Prodi Pendidikan Biologi, Universitas Muhammadiyah Makassar \\ Jalan Sultan Alauddin no.259 Makassar, Sulawesi Selatan-Indonesia 90221 \\ ${ }^{*}$ Corresponding author: anisa@unismuh.ac.id
}

\begin{tabular}{|c|c|}
\hline Informasi Artikel & ABSTRACT \\
\hline $\begin{array}{l}\text { Submit: } 05-02-2021 \\
\text { Diterima: } 25-05-2021 \\
\text { Dipublikasikan: } 02-06-2021\end{array}$ & $\begin{array}{l}\text { Students independently monitor the progress of their academic activities, such as } \\
\text { grades from courses and assignments. Students who are able to adapt quickly to the } \\
\text { learning process in higher education will certainly be able to carry out fairly solid } \\
\text { academic activities well. For this reason, students need to have good self-regulated } \\
\text { learning and self-efficacy. Therefore, this study aims to analyze the effect of self- } \\
\text { regulated learning and self-efficacy on academic achievement of students of Biology } \\
\text { Education Study Program, University of Muhammadiyah Makassar. This research is } \\
\text { ex post facto type. The population in this study were all students of the Biology } \\
\text { Education Study Program, University of Muhammadiyah Makassar. Data collection } \\
\text { techniques using a questionnaire. The data analysis technique used multiple linear } \\
\text { regression test. The results of data analysis show that the correlation between self- } \\
\text { efficacy and self-regulated learning with academic achievement has a very strong } \\
\text { relationship. It can be concluded that self-efficacy and self-regulated learning play an } \\
\text { important role in student academic achievement. Students who have high self- } \\
\text { efficacy and self-regulated learning will be able to adapt well in academic activities at } \\
\text { universities which are quite dense. So that it will help students to achieve brilliant } \\
\text { academic achievements. }\end{array}$ \\
\hline & Key words: self efficacy, self regulated learning, academic achievements \\
\hline Penerbit & ABSTRAK \\
\hline $\begin{array}{l}\text { Program Studi Pendidikan Biologi } \\
\text { FKIP Universitas Jambi, } \\
\text { Jambi- Indonesia }\end{array}$ & $\begin{array}{l}\text { Mahasiswa secara mandiri memantau perkembangan kegiatan akademiknya, seperti } \\
\text { nilai-nilai dari mata kuliah dan tugas yang diberikan. Mahasiswa yang mampu } \\
\text { beradaptasi secara cepat dengan proses pembelajaran di perguruan tinggi tentu } \\
\text { akan dapat menjalani aktivitas akademik yang cukup padat dengan baik. Untuk itu } \\
\text { mahasiswa perlu memiliki self regulated learning dan self efficacy yang baik. Oleh } \\
\text { karena itu penelitian ini bertujuan untuk menganalisis pengaruh self regulated } \\
\text { learning dan self efficacy terhadap prestasi akademik mahasiswa Prodi Pendidikan } \\
\text { Biologi Universitas Muhammadiyah Makassar. Penelitian ini berjenis ex post facto. } \\
\text { Populasi dalam penelitian ini adalah seluruh mahasiswa Prodi Pendidikan Biologi } \\
\text { Universitas Muhammadiyah Makassar. Teknik pengumpulan data menggunakan } \\
\text { kuesioner. Teknik analisis data menggunakan uji regresi linear berganda. Hasil } \\
\text { analisis data yang menunjukkan bahwa korelasi antara self efficacy dan self } \\
\text { regulated learning dengan prestasi akademik memiliki hubungan yang sangat kuat. } \\
\text { Dapat disimpulkan bahwa self efficacy dan self regulated learning berperan penting } \\
\text { terhadap prestasi akademik mahasiswa. Mahasiswa yang memiliki self efficacy dan }\end{array}$ \\
\hline
\end{tabular}


self regulated learning yang tinggi akan mampu beradaptasi dengan baik dalam kegiatan akademik di perguruan tinggi yang cukup padat. Sehingga hal tersebut akan membantu mahasiswa untuk meraih prestasi akademik yang gemilang.

Kata kunci: self efficacy, self regulated learning, prestasi akademik

\section{PENDAHULUAN}

Pendidikan merupakan salah satu usaha yang dilakukan untuk mempersiapkan generasi muda penerus bangsa. Sejalan dengan Undang-Undang Nomor 20 tahun 2003 tentang Sistem Pendidikan Nasional, Pasal 3, tujuan pendidikan nasional adalah mengembangkan potensi peserta didik agar menjadi manusia yang beriman dan bertakwa kepada Tuhan Yang Maha Esa, berakhlak mulia, sehat, berilmu, cakap, kreatif, mandiri, dan menjadi warga negara yang demokratis serta bertanggung jawab. Pendidikan pun memiliki tingkatan sesuai dengan perkembangan usia peserta didik, meliputi pendidikan anak usia dini, pendidikan dasar, dan pendidikan tinggi. Semakin tinggi jenjang pendidikan, peserta didik semakin dituntut kemandiriannya dalam kegiatan pembelajaran. Jenjang tertinggi dalam pendidikan formal adalah perguruan tinggi. Kegiatan akademik di perguruan tinggi memiliki perbedaan yang cukup besar dibandingkan dengan jenjang sekolah di bawahnya dalam kegiatan akademik.

Peserta didik yang belajar di perguruan tinggi biasa disebut dengan mahasiswa. Mahasiswa secara mandiri memantau perkembangan kegiatan akademiknya, seperti nilai-nilai dari mata kuliah dan tugas yang diberikan. Terlebih lagi kemajuan dan kecanggihan teknologi yang berkembang pesat yang menyajikan berbagai macam hiburan dan informasi menarik. Hal ini terkadang membuat mahasiswa lalai dalam melaksanakan kegiatan akademiknya dan memicu terjadinya prokrastinasi akademik di kalangan mahasiswa. Seperti penelitian yang dilakukan oleh (Anisa \& Ernawati, 2018) bahwa prokrastinasi akademik berkontribusi negatif terhadap hasil belajar. Prokrastinasi akademik merupakan kebiasaan menunda-nunda tugas yang dilakukan oleh seseorang. Jika kebiasaan menunda-nunda tugas dilakukan oleh mahasiswa tentu akan berpengaruh pada prestasi akademik.

Padatnya kegiatan akademik seorang mahasiswa tentu akan berpengaruh kepada prestasi yang diraih. Hal senada dikemukakan oleh (Siregar Ilham Khairi \& Putri, 2019) bahwa mahasiswa yang kurang mampu untuk beradaptasi dengan suasana belajar di perguruan tinggi dan berbagai tugas dapat menjadikan mahasiswa menjadi tertekan serta dapat memicu kondisi yang disebut stres akademik. Mahasiswa yang mampu untuk mengatur kegiatan akademiknya dengan baik tentu akan memiliki kesempatan meraih prestasi yang gemilang. Karena tidak sedikit mahasiswa yang mengalami beberapa hambatan dalam kegiatan akademik, seperti tugas yang tidak selesai, nilai tugas yang tidak maksimal dan nilai ujian yang rendah. Hal tersebut bisa disebabkan oleh mahasiswa masih melakukan adaptasi cara belajar antara sekolah dan perguruan tinggi.

Mahasiswa yang mampu beradaptasi secara cepat dengan proses pembelajaran di perguruan tinggi tentu akan dapat menjalani aktivitas akademik yang cukup padat dengan baik. Kemampuan mahasiswa untuk mengatur aktivitas akademiknya ini berkaitan dengan Self Regulated Learning yang 
dimiliki oleh mahasiswa. Seperti yang dikemukakan oleh (Barry J. Zimmerman \& Scunk, 2011) bahwa Self Regulated Learning merupakan kemampuan peserta didik untuk menerapkan dan mempertahankan kognisi, pengaruh dan perilaku yang secara sistematis berorientasi untuk mencapai tujuan pembelajaran. Hal senada dikemukakan oleh (S.Endler \& L.Kocovski, 2000) bahwa self regulated melibatkan penetapan tujuan, pemantauan serta evaluasi perilaku dan pemikiran. Self regulated learning berkaitan dengan usaha untuk meminimalisir ketidaksesuaian antara standar yang ditetapkan dan perilaku. Selain self regulated learning, mahasiswa juga perlu memiliki self efficacy yang baik. (Rustika, 2016) mengatakan bahwa self efficacy memiliki peranan yang penting dalam kehidupan keseharian seseorang. Self efficacy dapat mendukung seseorang untuk menggunakan potensi yang dimilikinya secara optimal. Self efficacy dapat mempengaruhi aspek kehidupan seseorang seperti prestasi.

Mahasiswa yang memiliki self efficacy yang tinggi tentu akan dapat menggunakan potensi yang dia miliki untuk meraih prestasi akademik. Hal ini didukung oleh penelitian yang dilakukan (Amir. H, 2016) bahwa efikasi diri mahasiswa memiliki pengaruh yang signifikasn serta bersifat linear terhdapa motivasi berprestasi. Semakin baik self efficacy yang dimiliki mahasiswa maka semakin meningkat pula motivasi berprestasinya. Berdasarkan hal tersebut maka dilaksanakan penelitian untuk menganalisis pengaruh self regulated learning self efficacy dan self regulated learning terhadap prestasi akademik mahasiswa Prodi Pendidikan Biologi Universitas Muhammadiyah Makassar.

\section{METODE PENELITIAN}

Penelitian ini berjenis ex-post facto yang bersifat korelasi (Sugiyono, 2017). Variabel penelitian ini terdiri dari dua variabel bebas yakni self efficacy dan self regulated learning serta satu variabel terikat yaitu prestasi belajar. Desain hubungan antara variabel bebas $(X 1, X 2)$ dan variabel terikat $(Y)$ tersebut dapat dilihat pada Gambar 1

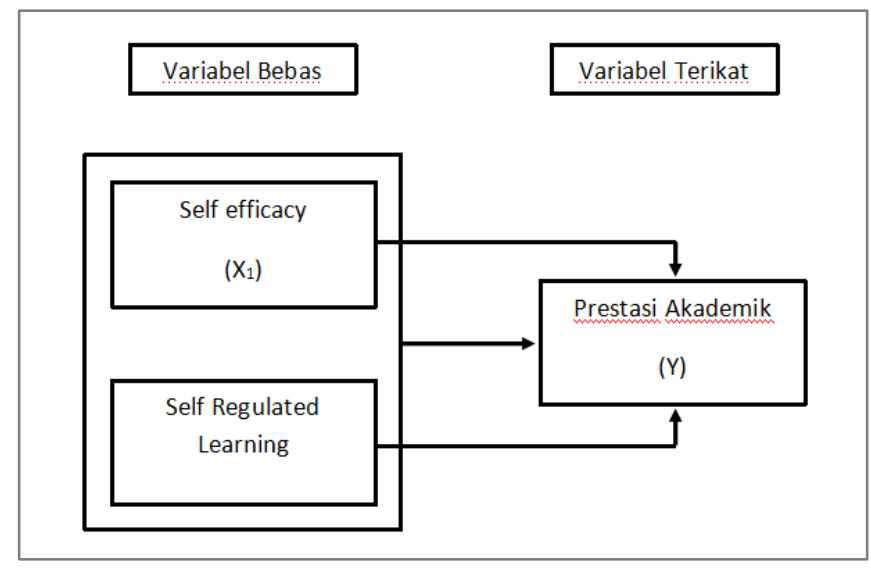

Gambar 1. Desain Hubungan Variabel

Self efficacy yang dimaksud dalam penelitian ini adalah keyakinan mahasiswa terhadap diri untuk menjalani kegiatan akademik. Indikator self efficacy; yakin dapat menyelesaikan tugas tertentu, yakin dapat memotivasi diri untuk melakukan tindakan yang diperlukan untuk menyelesaikan tugas, yakin bahwa diri dapat berusaha dengan keras, gigih dan tekun, yakin bahwa diri dapat bertahan 
menghadapi hambatan dan kesulitan serta yakin dapat menyelesaikan masalah di berbagai situasi. Berupa skor yang diperoleh responden melalui pemberian kuesioner berbantuan Google Form. Kuesioner sebelumnya melalui uji validitas serta diujicobakan sebelumnya.

Self Regulated Learning yang dimaksud dalam penelitian ini adalah kemampuan mahasiswa dalam melakukan aktivitas belajar yang ditunjukkan oleh indikator yakni; metakognisi, motivasi dan perilaku dalam proses belajar berupa skor yang diperoleh responden melalui pemberian angket kuesioner regulasi diri berbantuan Google Form. Hasil belajar yang dimaksud dalam penelitian ini adalah hasil belajar yang dicapai oleh mahasiswa tahun ajaran 2019/2020, yang diambil dari nilai mata kuliah Genetika yang diperoleh dari Dosen pengampu mata kuliah.

Intrumen yang digunakan berupa angket berbantuan Google Form yang digunakan untuk mengumpulkan data self efficacy dan self regulated learning. Serta dokumentasi nilai hasil belajar mahasiswa pada mata kuliah Genetika. Teknik analisis data meliputi uji prasyarat yakni uji normalitas dan linearitas yang dilakukan sebelum melakukan uji hipotesis yakni menggunakan regresi linear ganda.

\section{HASIL PENELITIAN DAN PEMBAHASAN}

\section{A. Analisis Data}

Hipotesis penelitian ini adalah ada pengaruh self efficacy dan self regulated learning terhadap prestasi akademik mahasiswa Prodi Pendidikan Biologi Universitas Muhammadiyah Makassar.Untuk membuktikannya maka dilakukan regresi linear berganda.

$H_{0}: \beta_{1}=0$

$H_{1}=\beta_{1}>0$

$\mathrm{H}_{0} \quad$ : Tidak terdapat pengaruh Self efficacy dan Self Regulated Learning terhadap prestasi akademik mahasiswa Prodi Pendidikan Biologi Universitas Muhammadiyah Makassar

$\mathrm{H}_{1} \quad$ : Terdapat pengaruh Self efficacy dan Self Regulated Learning terhadap prestasi akademik mahasiswa Prodi Pendidikan Biologi Universitas Muhammadiyah Makassar

Hasil regresi yang telah dilakukan adalah koefisien regresi dengan konstanta "a" sebesar 64.767 dengan nilai koefisien b1 adalah 1.826 dan koefisien b2 adalah 0.390. Persamaan garis regresi adalah $\hat{Y}=89.886+1.826 \times 1+0.390 \times 2$. Analisis korelasi sederhana terhadap skor media sosial $(\mathrm{X})$ dan skor hasil belajar biologi $(Y)$ menunjukkan koefisien korelasi ry sebesar 0,35 . Pengujian koefisien korelasi tersebut menggunakan uji t yang dapat dilihat pada tabel 1 . 
Tabel 1. Uji Signifikan Koefisien Korelasi $\mathrm{r}_{\mathrm{y} 1,2}$

\begin{tabular}{cccccc}
\hline \multirow{2}{*}{$\begin{array}{c}\text { Cacah Observasi } \\
(\mathrm{df})\end{array}$} & Koefisien Korelasi & Koefisien Determinasi & t Hitung & \multicolumn{2}{c}{ t Tabel } \\
\cline { 3 - 5 } & & & & $\alpha=0.05$ & $\alpha=0.01$ \\
\hline 6 & 0.857 & 0.123 & 2.34 & 1,65 & 2,33 \\
\hline
\end{tabular}

Setelah melalui uji prasyarat yakni uji normalitas dan linearitas maka dilakukan uji hioptesis. Hasil analisis regresi linear berganda menunjukkan bahwa terdapat pengaruh self efficacy dan self regulated learning terhadap prestasi akademik mahasiswa Prodi Pendidikan Biologi Universitas Muhammadiyah Makassar. Berdasarkan hasil uji hipotesis dimana t hitung lebih besar dibanding $t$ tabel maka dapat disimpulkan bahwa semakin tinggi self efficacy dan self regulated learning maka semakin tinggi pula prestasi akademik mahasiswa. Sementara itu koefisien korelasi $r_{y 1,2}$ sebesar 0.857 berdasarkan pengkategorian interpretasi koefisien korelasi menurut (Arikunto, 2002) bahwa koefisien korelasi berada pada kategori sangat kuat.

Hasil uji hipotesis menunjukkan ada pengaruh self regulated learning dan self efficacy terhadap prestasi akademik mahasiswa Prodi Pendidikan Biologi Universitas Muhammadiyah Makassar. Tingkat hubungan antar variabel juga menunjukkan hubungan yang sangat kuat yang ditandai dengan tingginya koefisien korelasi. Hal tersebut dapat memberikan gambaran bahwa keberadaan self regulated learning dan self efficacy dalam diri mahasiswa itu cukup penting.

Mahasiswa dengan self efficacy yang tinggi memiliki prestasi akademik yang bagus karena mereka memiliki tingkat kepercayaan diri yang tinggi akan kemampuannya. Berdasarkan jawaban kuesioner mahasiswa menunjukkan bahwa $61,7 \%$ mahasiswa yakin untuk mengerjakan tugas-tugas akademik yang diberikan walaupun mereka sangat lelah dan menyelesaikannya tepat waktu. Seperti yang dikemukakan oleh (Widyaninggar, 2015) seseorang dengan self efficacy diri yang tinggi memiliki kepercayaan diri yang tinggi dibanding temannya, memiliki rasa ingin tahu yang tinggi, memiliki banyak solusi untuk menyelsaikan masalah dan tidak malu bertanya.

Selain itu mahasiwa dengan tingkat self efficacy yang tinggi akan beradaptasi dengan baik dengan kegiatan akademik di universitas yang cukup padat. Kegiatan akademik dibangku kuliah tentu berbeda dengan kegiatan akademik di bangku sekolah. Hal ini menuntut mahasiswa untuk beradaptasi dengan baik di bangku kuliah. Hal ini didukung juga oleh (Mahmudi \& Suroso, 2014) bahwa self efficacy pada diri seseorang dapat membantunya untuk meningkatkan kemampuannya untuk menyesuaikan diri.

Self efficacy yang tinggi akan membantu mahasiswa untuk mengatasi stres di tengah kegiatan akademik yang cukup padat. Saat mereka mengalami kegagalan mereka mampu mengendalikan perasaan kecewa mereka dan bangkit kembali. Hal ini berdasarkan jawaban kuesioner yang diberikan bahwa sebagian besar mahasiswa mereka merasa mampu untuk mengendalikan perasaan kecewa 
saat gagal untuk mendapatkan nilai yang baik pada beberapa mata kuliah. Seperti yang dikemukakan oleh (Afnan, 2020)berdasarkan hasil penelitiannya bahwa semakin tinggi self efficacy yang dimiliki oleh mahasiswa maka semakin rendah pula stres yang dialami oleh mahasiswa pada fase quarter life crisis dan sebaliknya.

Hasil kuesioner juga menunjukkan bahwa mahasiswa dengan self efficacy yang baik merasa mampu untuk mendapatkan nilai yang baik pada mata kuliah yang dijalaninya. Hal ini serupa yang dikemukakan oleh (Kusrieni, 2014) berdasarkan penelitiannya bahwa peserta didik dengan self efficacy yang tinggi, cenderung memiliki kecenderungan untuk mencontek yang rendah. Mereka percaya akan kemampuan yang dimilikinya dan memperoleh nilai yang baik sesuai dengan kemampuannya. (Mahmudi \& Suroso, 2014) juga berpendapat bahwa peserta didik yang memiliki self efficacy yang tinggi juga memiliki kemampuan yang baik dalam penyesuaian diri dalam belajar. Hal ini tentu akan berpengaruh pada prestasi akademik. Pendapat lain juga diutarakan (Permana et al., 2017) berdasarkan penelitiannya bahwa peserta diik yang memiliki tingkat self efficacy yang tinggi memiliki tingkat kecemasan yang rendah dalam menghadapi ujian. Jika peserta didik memiliki tingkat kecemasan yang rendah menghadapi ujian, maka mereka akan lebih siap menjalaninya.

Selain didukung oleh self efficacy, prestasi akademik mahasiswa juga didukung oleh self regulated learning yang baik pula. Melalui self regulated learning yang baik mahasiswa mampu untuk mengatur sendiri pola belajar mereka sesuai dengan tujuan yang ingin mereka capai. Seperti yang diungkapkan oleh (Rachmah, 2015) berdasarkan hasil penelitiannya pada mahasiswa Program Pascasarjana, mahasiswa menyadari bahwa mereka memiliki sejumlah aktivitas yang yang harus dijalani, dengan kemampuan regulasi diri dalam belajar membuat mereka mampu untuk meraih prestasi akademik yang tinggi. Hal senada juga dikemukakan oleh (Manab, 2016)bahwa regulasi yang baik akan mengarahkan seseorang menuju perilaku yang positif.

Berdasarkan hasil kuesioner, mahasiswa dengan self regulated learning yang baik memiliki beberapa strategi yang mereka gunakan untuk belajar, mereka juga menyiapkan tempat yang nyaman sebelum belajar dan mempersiapkan diri mereka jika dosen memberitahukan akan diadakan ujian. Hal inilah yang mampu mendukung mereka untuk mencapai prestasi akademik yang baik. Mahasiswa dengan kemampuan self regulated learning yang baik juga dapat mengatur berbagai aktivitas mereka yang cukup padat. Seperti yang dikemukakan oleh (Husna et al., 2014)self regulated learning melibatkan berbagai aspek dalam diri mahasiswa, yang melibatkan keseuaian, kesinambungan serta fokus antara tindakan dengan target yang direncanakan untuk dicapai.

Berdasarkan hasil penelitian yang telah dilakukan self effiicacy dan self regulated learning memberikan pengaruh positif terhadap pencapaian prestasi akademik mahasiswa. Keduanya memiliki hubungan yang kuat dengan prestasi akademik. Prestasi akademik tidaklah dapat lepas dari faktor eksternal dan internal yang mempengaruhinya. Salah satu faktor yang mempengaruhi prestasi akademik mahasiswa adalah dukungan orang tua. Dukungan orang tua akan membuat mahasiswa memiliki rasa percaya diri yang tinggi akan dirinya dan mampu melewati berbagai hambatan. 
Seperti saat ini kemajuan dan kecanggihan teknologi yang menyajikan berbagai macam hiburan dan informasi menarik. Hal ini terkadang membuat mahasiswa lalai dalam melaksanakan kegiatan akademiknya dan memicu terjadinya prokrastinasi akademik di kalangan mahasiswa.

\section{SIMPULAN}

Berdasarkan hasil penelitian yang telah dilakukan, maka dapat disimpulkan bahwa self efficacy dan self regulated learning berperan penting terhadap prestasi akademik mahasiswa. Hal tersebut dibuktikan melalui hasil analisis data yang menunjukkan bahwa korelasi antara self efficacy dan self regulated learning dengan prestasi akademik memiliki hubungan yang sangat kuat. Mahasiswa yang memiliki self efficacy dan self regulated learning yang tinggi akan mampu beradaptasi dengan baik dalam kegiatan akademik di perguruan tinggi yang cukup padat. Sehingga hal tersebut akan membantu siswa untuk meraih prestasi akademik yang gemilang.

\section{UCAPAN TERIMA KASIH}

Penulis mengucapkan terima kasih kepada semua pihak yang telah membantu terlaksananya penelitian ini, terkhusus kepada Ketua Prodi Pendidikan Biologi Universitas Muhammadiyah Makassar yang telah mendukung penelitian ini. Serta kepada mahasiswa Prodi Pendidikan Biologi Universitas Muhammadiyah Makassar yang telah bersedia menjadi responden.

\section{RUJUKAN}

Afnan. (2020). Hubungan Efikasi Diri dengan Stress Pada Mahasiswa yang Berada dalam Fase Quarter Life Crisis. Jurnal Kognisia.

Amir. H. (2016). Korelasi Pengaruh Faktor Efikasi Diri dan Manajemen Diri Terhadap Motivasi Berprestasi Padamahasiswa Pendidikan Kimia Unversitas Bengkulu. Manajer Pendidikan.

Anisa, A., \& Ernawati, E. (2018). PENGARUH PROKRASTINASI AKADEMIK TERHADAP HASIL BELAJAR BIOLOGI SISWA SMA NEGERI DI KOTA MAKASSAR. Jurnal Biotek. https://doi.org/10.24252/jb.v6i2.6256

Arikunto, S. (2002). Metodologi Penelitian Suatu Pendekatan Proposal. 2017.

Barry J. Zimmerman, \& Scunk, D. H. (2011). Handbook of Self Regulation of Learning and Performance (1st ed.). Routledge Taylor and Francis Group.

Husna, A. N., Hidayati, F. N. R., \& Ariati, J. (2014). REGULASI DIRI MAHASISWA BERPRESTASI. Jurnal Psikologi Undip. https://doi.org/10.14710/jpu.13.1.50-63

Kusrieni, D. (2014). HUBUNGAN ANTARA KONSEP DIRI AKADEMIK,EFIKASI DIRI AKADEMIK, HARGA DIRI DANPROKRASTINASI AKADEMIK PADA SISWA SMPNEGERI DI KOTA MALANG. PSIKOPEDAGOGIA, 3(2), 100-111. https://core.ac.uk/download/pdf/295348711.pdf

Mahmudi, M. H., \& Suroso. (2014). Efikasi Diri,Dukungan SosialDan Penyesuaian DiriDalam Belajar. Persona, Jurnal Psikologi Indonesia, 3(2), 183-194. http://jurnal.untagsby.ac.id/index.php/persona/article/view/382/340

Manab, A. (2016). Memahami regulasi diri: Sebuah tinjauan konseptual. Psychology Humanity. Permana, H., Harahap, F., \& Astuti, B. (2017). HUBUNGAN ANTARA EFIKASI DIRI DENGAN KECEMASAN DALAM MENGHADAPI UJIAN PADA SISWA KELAS IX DI MTS AL HIKMAH BREBES. Hisbah: Jurnal Bimbingan Konseling Dan Dakwah Islam. https://doi.org/10.14421/hisbah.2016.132-04

Rachmah, D. N. (2015). Regulasi Diri dalam Belajar pada Mahasiswa yang Memiliki Peran Banyak. Jurnal Psikologi. https://doi.org/10.22146/jpsi.6943

Rustika, I. M. (2016). Efikasi Diri: Tinjauan Teori Albert Studi, Program Fakultas, Psikologi Universitas, Kedokteran. Buletin Psikologi. 
S.Endler, N., \& L.Kocovski, N. (2000). Self-Regulation and Distress in Clinical PsychologyS.Endler, N., \& L.Kocovski, N. (2000). Self-Regulation and Distress in Clinical Psychology. In Handbook of SelfRegulation (pp. 569-599). Elsevier Inc. https://www.sciencedirect.com/science/article/pii/B9. In Handbook of Self-Regulation (pp. 569-599). Elsevier Inc.

https://www.sciencedirect.com/science/article/pii/B9780121098902500469

Siregar Illham Khairi, \& Putri, S. R. (2019). Hubungan Self-Efficacy dan Stres Akademik Mahasiswa. CONSILIUM : BERKALA KAJIAN KONSELING DAN ILMU KEAGAMAAN, 6(2), 91-95.

http://jurnal.uinsu.ac.id/index.php/consilium/article/view/6386

Sugiyono. (2017). Metode Penelitian Kuantitatif, Kualitatif dan R \& D.Bandung:Alfabeta. Metode Penelitian Kuantitatif, Kualitatif Dan R \& D.Bandung:Alfabeta. https://doi.org/10.1017/CB09781107415324.004

Widyaninggar, A. A. (2015). Pengaruh Efikasi Diri dan Lokus Kendali (Locus of Control) Terhadap Prestasi Belajar Matematika. Formatif: Jurnal IImiah Pendidikan MIPA. https://doi.org/10.30998/formatif.v4i2.143 